\title{
Self-Care Practice and Associated Factors Among Individuals with Diabetes Mellitus in Northeast Ethiopia
}

This article was published in the following Dove Press journal: Journal of Multidisciplinary Healthcare

\author{
Sine Zewde Gebre' \\ Betregiorgis Zegeye (iD ${ }^{2}$ \\ Mitku Mammo Taderegew (iD ${ }^{3}$ \\ 'Emergency Department, Debre Berhan \\ Referral Hospital, Debre Berhan, \\ Ethiopia; ${ }^{2} \mathrm{HaSET}$ Maternal and Child \\ Health Research Program, Shewarobit \\ Field Office, Shewarobit, Ethiopia; \\ ${ }^{3}$ Department of Biomedical Sciences, \\ College of Medicine and Health Sciences, \\ Wolkite University, Wolkite, Ethiopia
}

Correspondence: Mitku Mammo Taderegew Department of Biomedical Sciences, School of Medicine, College of Medicine and Health Sciences, Wolkite University, P.O. Box 07 Wolkite, Ethiopia

Email mitkumamo@gmail.com
Purpose: Self-care practices in diabetes patients are crucial to keep the illness under managed and prevent complications. Despite this, relatively little information is available regarding the level of self-care practice and associated factors among individuals with diabetes mellitus in the study area. Therefore, this study aimed to assess self-care practice and its associated factors among individuals with diabetes mellitus in Deber Berhan referral hospital, Northeast Ethiopia.

Patients and Methods: A hospital-based cross-sectional study was conducted among 405 diabetes mellitus patients from May 1 to June 30, 2020. The data were collected using a pretested structured interviewer-administered questionnaire. The data were entered into Epi-data manager version 4.4.1.0 and finally exported into SPSS-24 software for analysis. To identify the predictor of self-care practice, binary logistic regression analysis was done. The result of the analysis was presented in a crude and adjusted odds ratio with $95 \%$ confidence intervals. All tests were two-sided, and $\mathrm{P}<0.05$ was considered statistically significant.

Results: About 181 (44.7\%) of participants had good self-care practice. On a multivariate logistic regression analysis, educational status of the participants (with no formal education $(\mathrm{AOR}=0.12,95 \% \mathrm{CI}: 0.03-0.42)$, can read and write $(\mathrm{AOR}=0.23,95 \% \mathrm{CI}: 0.07-0.75)$, and secondary school $(\mathrm{AOR}=0.28,95 \% \mathrm{CI}: 0.09-0.88)$ ), type $1 \mathrm{DM}(\mathrm{AOR}=0.27,95 \% \mathrm{CI}$ : $0.09-0.79)$, family history of DM (AOR $=3.71,95 \% \mathrm{CI}: 1.37-10.07)$, and treatment satisfaction $(\mathrm{AOR}=4.41,95 \% \mathrm{CI}: 1.52-8.59)$ were significantly associated with self-care practice.

Conclusion: More than half of the respondents had poor self-care practices. Educational status, types of DM, family history of DM, and treatment satisfaction were the predictors of self-care practices among individuals with DM.

Keywords: self-care practices, diabetes mellitus, associated factors, Ethiopia

\section{Introduction}

Diabetes mellitus (DM) is a chronic non-communicable disease which is characterized by hyperglycemia due to absolute or relative deficiency of insulin. ${ }^{1}$ DM has acute or chronic complications, which are responsible for the majority of morbidity and mortality associated with the disease. Therefore requires continuing medical care and ongoing patient self-management education and prevent acute complications and to reduce the risk of long-term complications. When it is not prevented and properly managed, diabetes is one of the major causes of premature illness and death worldwide which results in 5.1 million deaths in 2013 . $^{2,3}$ 
Despite the great strides that have been made in the treatment of diabetes in recent years, many patients do not achieve optimal outcomes and still experience devastating complications due to inadequate self-care practice. Poor self-care practice increases the incidence and prevalence of complications resulting in increased morbidity and mortality. ${ }^{4}$ Self-care practices in diabetes patients are crucial to keep the illness under managed and prevent complications. Effective management of diabetes will be a difficult task without an adequate understanding of the existing level of practice related to diabetes self-care. ${ }^{1}$

Self-care practices are undertaken by people with or at risk of developing diabetes to successfully delay the onset and manage the disease on their own, it includes healthy eating habits, being regular physical activity, regular monitoring of blood glucose and blood pressure level, taking medication properly, and reduce other risks of disease. Self-care practice in diabetes is positively correlated with good glycemic control, reduction of complications, and improvement in the quality of life. Self-care in diabetes is a critical factor to keep the disease under manage and about $95 \%$ of the care of the diseases usually carried out by the affected individual or their families consists of self-monitoring of blood glucose (SMBG), nutrition, physical activity, and compliance to medications. ${ }^{2,5}$

Despite this, relatively little information is available regarding the level of self-care practice and associated factors among individuals with DM in the study area. Therefore, this study aims to assess self-care practice and its associated factors among individuals with DM in Deber Berhan, Northeast Ethiopia. The finding of the study provides baseline information and fills the gap-related to the level of selfcare practice and associated factors. Also, the findings of this study will help program managers and policymakers to consider self-care practices in health care planning. The finding of this study can also serve as baseline information for other studies with similar interests in the future.

\section{Patients and Methods}

\section{Study Design, Setting, and Population}

An institutional-based cross-sectional study was conducted among diabetes mellitus patients at the out-patient DM clinic of Debre Berhan referral hospital (DBRH) in Northeast Ethiopia, from May 1 to June 30, 2020. DBRH is found in Debre Berhan city of Amhara regional state, which is located $130 \mathrm{~km}$ northeast of Addis Ababa, the capital city of Ethiopia.

Regarding health service in the city, there are one government and one private hospital, three government health centers, four health posts, and 8 private clinics. DBRH is the only government hospital in the city and it provides preventive, curative, and rehabilitative services for the 3.5 million catchment population as a referral center.

Different units provide services for clients in the hospital. Among these clinics, the diabetes follow-up clinic is one of the chronic follow-up clinics of the hospital providing services from Monday to Friday with a minimum follow-up appointment every 2 weeks to a maximum of 2 months. Diabetes-related care services were provided by general practitioners, internists, senior medical students, and nurses. There is no routine diabetes health education program at the clinic but it is occasionally given by nurses with minimal support from physicians. Health care expenses in Ethiopia including in the study area were largely covered by out-of-pocket expenditure.

The source populations of the study were all adults with DM who attended follow-up at the out-patient DM clinic of DBRH during the study period. All adults with type 1 and type $2 \mathrm{DM}$ who have a follow-up for at least six months in the out-patient DM clinic were eligible for the study whereas those individuals who were critically ill and mentally incompetent were excluded.

\section{Sample Size Determination and Sampling Techniques}

The sample size of the study was determined using a single population proportion formula by considering $60.3 \%$ proportion $(\mathrm{P})$ of self-care practice among individuals with $\mathrm{DM},{ }^{6}$ a $95 \%$ confidence interval, $5 \%$ margin of error, and $10 \%$ nonresponse rate. Hence, the final calculated sample size was 405 .

The lists of respondents or sampling frames were prepared from the updated registry book of the follow-up clinics of the hospital. Then, the study participants were selected by using a systematic random sampling technique in order of their appointments. The first individual participant was selected by lottery method using their card number, and then every other participant was selected based on their order of entry for follow up. In cases where the patients have two follow-up appointments within a study period, the patient's appointment date was checked and he/ she was excluded from the interview.

\section{Data Collection Procedures}

Two data collectors and one supervisor were recruited for the study. After informing the purpose of the study and the importance of their participation, data were collected by exit 
interviews using a pre-tested interviewer-administered structured questionnaire. The exit interview was aimed to collect information about the socio-demographic variables, healthrelated variables, DM knowledge, treatment satisfaction, and self-care practice of participants. After the exit interview of each study participant, clinical data such as types of DM, presence of comorbidity, and current treatment profile were collected by reviewing their medical records.

The questionnaire was first prepared in English and translated to Amharic by an expert who has good ability in the two languages, and then another expert retranslated back to English to ensure its consistency. The two days training was given for data collectors and supervisors on the objective of the study and each component of the questionnaire. To ensure the consistency and validity of the questioner a pretest was conducted on $5 \%$ of the actual sampled population in the Debre Sina hospital, which was not part of the actual data collection area. The reliability of the study participants was examined by Cronbach's alpha $(\alpha=0.81)$ which shown high internal consistency. The internal validity of the questioner was also assessed by comparing questionnaire responses with the objectives of the study during the pre-test. After a pre-test correction was made accordingly before the actual data collection. Moreover, the collected data were checked daily by the principal investigator and supervisors to safeguard its completeness. To minimize bias, interviews were conducted in an area with adequate confidentiality and privacy and without any involvement of health care providers working in that hospital.

\section{Operational Definitions}

Glycemic control: Glycemic status was considered as good glycemic control if an average of four consecutive fasting blood glucose measurement $80-130 \mathrm{mg} / \mathrm{dL}$ and poor glycemic control if an average of blood glucose values on four consecutive visits were $>130$ or $<80 \mathrm{mg} / \mathrm{dL}{ }^{1}$

Diabetes-related complications: If participants had a documented record of at least one of these; diabetesrelated retinopathy, diabetes nephropathy, neuropathy, and diabetic foot ulcer.

Self-care practice: It is a daily regimen task that the individual patients were performed to manage diabetes on their behalf (dietary practice, exercise, medication, daily foot care, monitoring blood glucose). ${ }^{7}$ Diabetes self-care practice was assessed by participants' responses to the 15item Summary of Diabetes Self-Care Activities (SDSCA) in the last 7 days. Response choices for each question were range from 0 to 7 based on the number of days on which the indicated behavior was performed. The overall mean score was estimated by summation of each item of the scale and divided by the total number of questions. Therefore, after calculating the overall mean score, participants who scored equal to or greater than the mean score were classified as having good diabetes self-care practice and those who scored below the mean were considered as having poor self-care practice. ${ }^{8}$

Regular checkup: If patients undertaking investigations at least once within three months. ${ }^{9}$

Regular exercise: If the participant performed 30 minutes of activity involved in walking and running for at least five days per week. ${ }^{9}$

Knowledge: The knowledge level was assessed by the participants' responses to 15 knowledge-related questions. Each correct response was assigned " 1 score" and an incorrect response and do not know the response was given "0 scores". Then a total score was computed and the mean was used as a cut-off point. Participants were considered as having adequate knowledge if they respond to greater than or equal to the mean score (7.5) of the 15 knowledge-related questions. If they respond to less than the mean score of knowledge questions, considered as having inadequate knowledge.

Treatment satisfaction: The satisfaction level regarding service/treatment provided during their current visit was assessed using the diabetes treatment satisfaction questionnaire (DTSQ). DTSQ was presented by using a 5-Likert scale (1-very dissatisfied, 2-dissatisfied, 3-neutral, 4-satisfied, and 5-very satisfied). ${ }^{9}$

The participant was considered as satisfied with the current treatment if the score was more than or equals to \{ (total highest score-total lowest score) $/ 2\}+$ total lowest score and dissatisfied if less than \{(total highest score-total lowest score) $/ 2\}+$ total lowest score obtained from the demarcation threshold formula. From the finding of this research, the total highest score was 30 , and the total lowest score was 8 . Hence, $(30-8 / 2)+8=19$. Therefore respondents scored more than or equal to 19 were considered satisfied and those scored less than 19 were considered dissatisfied in this research.

\section{Data Processing and Analysis}

Before entry, the collected data were checked for completeness, then coded, and entered, into Epi-data manager version 4.4.1.0, and finally exported into SPSS-24 software for analysis. Descriptive statistics including frequency distribution cross-tabulation and summary measures were computed and the result was presented in tables.

Binary logistic regression analysis was used to identify the predictors of self-care practice among 
diabetes. All predictors having a p-value $<0.20$ in the bivariate analysis were included in a logistic regression model to manage the effect of a confounder. Finally, the degree of association was presented in the odds ratio with $95 \%$ confidence intervals. All tests were two-sided and $\mathrm{P}<0.05$ was considered statistically significant.

\section{Result}

\section{Socio-Demographic Characteristics of the Study Participants}

A total of 405 DM patients, of which 205 (50.6\%) were males, were included in the study. The mean age $( \pm \mathrm{SD})$ of the participants was $44.13( \pm 8.20)$ years, and more than half of the participants (52.8\%) were below 45 years old. Nearly threefifths $(62.7 \%)$ of the participants were from an urban area and $254(62.7 \%)$ were married. The majority $(82.7 \%)$ of the respondents were living with family and $325(80.2 \%)$ were orthodox Christian by religion (Table 1).

\section{Clinical Characteristics of Study Participants}

Of the total of the respondents, 280 (69.1\%) were types $2 \mathrm{DM}$ and more than half (53.6\%) of the participants were currently on oral hypoglycemic agents. More than half of the respondents $(52.3 \%)$ had no family history of DM. One hundred and twenty-three $(30.4 \%)$ of the participants had a comorbid disease. The most common comorbidity $(72.3 \%)$ was hypertension. The majority $(89.6 \%)$ of the respondents did not have glucometer at home, and only $26(6.4 \%)$ of respondents was a member of the Ethiopian diabetic association. The majority of respondents (94.6\%) had no social support, and more than half $(52.6 \%)$ of them reported that they did not get diabetes education. More than half of the respondents (54.6\%) had poor glycemic control and nearly two-fifth (39.8\%) were with at least one documented record of diabetes-related complications (Table 2).

\section{Knowledge of the Study Participants}

The majority of the study participants $(85.7 \%)$ stated eating food lower in fat can reduce the risk of developing adverse outcomes in the different organs of the body, and $317(78.3 \%)$ of them said exercise affect the blood glucose level. In the majority $(82.2 \%)$ of the participants heartrelated disease identified as the main complication of diabetes. Overall, 233 (57.5\%) of respondents had inadequate diabetes knowledge (Table 3).
Table I Socio-Demographic Characteristics of the Study Participants at Debre Berhan Referral Hospital, Northeast Ethiopia, $2019(n=405)$

\begin{tabular}{|c|c|c|c|}
\hline Variables & Category & $\begin{array}{l}\text { Frequency } \\
(n=405)\end{array}$ & $\begin{array}{l}\text { Percent } \\
\text { (\%) }\end{array}$ \\
\hline \multirow[t]{2}{*}{ Gender } & Male & 205 & 50.6 \\
\hline & Female & 200 & 49.4 \\
\hline \multirow[t]{3}{*}{ Age (years) } & $15-44$ & 147 & 36.3 \\
\hline & $35-54$ & 135 & 33.3 \\
\hline & $>54$ & 123 & 30.4 \\
\hline \multirow[t]{3}{*}{ Marital Status } & Married & 254 & 62.7 \\
\hline & Single & 99 & 24.4 \\
\hline & Widowed/divorced/ & 52 & 12.8 \\
\hline \multirow{5}{*}{$\begin{array}{l}\text { Educational } \\
\text { level }\end{array}$} & Illiterate & 114 & 28.1 \\
\hline & Can read and write & 102 & 25.2 \\
\hline & Primary school & 52 & 12.8 \\
\hline & Secondary school & 83 & 20.5 \\
\hline & College and above & 54 & 13.3 \\
\hline \multirow[t]{4}{*}{ Occupation } & Self-employed & 127 & 31.4 \\
\hline & Government & 114 & 28.1 \\
\hline & employed & & 254 \\
\hline & $\begin{array}{l}\text { House wife } \\
\text { Others* }\end{array}$ & $\begin{array}{l}103 \\
61\end{array}$ & $\begin{array}{l}25.4 \\
15.1\end{array}$ \\
\hline \multirow[t]{2}{*}{ Residence } & Urban & 254 & 62.7 \\
\hline & Rural & $|5|$ & 37.3 \\
\hline Monthly & $<5000$ & 177 & 43.7 \\
\hline income (ETB) & $\geq 5000$ & 228 & 56.3 \\
\hline
\end{tabular}

Note: Others* include student and unemployed.

Abbreviation: ETB, Ethiopian birrr.

\section{Treatment Satisfaction of Diabetes Patients}

Overall, nearly three-fourth $(75.1 \%)$ of respondents were unsatisfied with the current diabetes treatment care they were given (Table 4).

\section{Self-Care Practice}

The majority $(87.7 \%)$ of the respondents had self-care practice of taking recommended medication, nearly threefifth $(60.2 \%)$ had self-care practice of regular physical activity over 30 minutes more than five days, and 240 $(59.3 \%)$ of respondents reported they checked their feet every day. The overall mean score for self-care among the study participants was 3.2 ( $\mathrm{SD} \pm 0.7$ ). Overall, 181 (44.7\%) of participants had good self-care practices (Table 5). 
Table 2 Clinical Characteristics of the Study Participants at Debre Berhan Referral Hospital, Northeast Ethiopia, 2019 $(n=405)$

\begin{tabular}{|c|c|c|c|}
\hline Variables & Category & $\begin{array}{l}\text { Frequency } \\
(n=405)\end{array}$ & $\begin{array}{l}\text { Percent } \\
(\%)\end{array}$ \\
\hline Type of DM & $\begin{array}{l}\text { Type } 1 \\
\text { Type } 2\end{array}$ & $\begin{array}{l}125 \\
280\end{array}$ & $\begin{array}{l}30.9 \\
69.1\end{array}$ \\
\hline Types of current treatment & $\begin{array}{l}\text { Oral } \\
\text { medication } \\
\text { Insulin } \\
\text { injection }\end{array}$ & $\begin{array}{l}217 \\
188\end{array}$ & $\begin{array}{l}53.6 \\
46.4\end{array}$ \\
\hline Comorbidity & $\begin{array}{l}\text { Yes } \\
\text { No }\end{array}$ & $\begin{array}{l}123 \\
282\end{array}$ & $\begin{array}{l}30.4 \\
69.6\end{array}$ \\
\hline Family history of DM & $\begin{array}{l}\text { Yes } \\
\text { No } \\
\text { Did not } \\
\text { know }\end{array}$ & $\begin{array}{l}149 \\
212 \\
44\end{array}$ & $\begin{array}{l}36.8 \\
52.3 \\
10.9\end{array}$ \\
\hline Knowing current FBS & $\begin{array}{l}\text { Yes } \\
\text { No } \\
\text { I do not } \\
\text { know }\end{array}$ & $\begin{array}{l}351 \\
29 \\
25\end{array}$ & $\begin{array}{l}86.7 \\
7.2 \\
6.2\end{array}$ \\
\hline Diabetic education & $\begin{array}{l}\text { No never } \\
\text { Sometimes } \\
\text { Regularly }\end{array}$ & $\begin{array}{l}213 \\
149 \\
43\end{array}$ & $\begin{array}{l}52.6 \\
36.8 \\
10.6\end{array}$ \\
\hline $\begin{array}{l}\text { Members of Ethiopian diabetic } \\
\text { association }\end{array}$ & $\begin{array}{l}\text { Yes } \\
\text { No } \\
\text { I do not } \\
\text { know }\end{array}$ & $\begin{array}{l}26 \\
339 \\
40\end{array}$ & $\begin{array}{l}6.4 \\
83.7 \\
9.9\end{array}$ \\
\hline Social support & $\begin{array}{l}\text { Yes } \\
\text { No }\end{array}$ & $\begin{array}{l}22 \\
383\end{array}$ & $\begin{array}{l}5.4 \\
94.6\end{array}$ \\
\hline Glucometer at home & $\begin{array}{l}\text { Yes } \\
\text { No }\end{array}$ & $\begin{array}{l}42 \\
363\end{array}$ & $\begin{array}{l}10.3 \\
89.7\end{array}$ \\
\hline Glycemic control & $\begin{array}{l}\text { Good } \\
\text { Poor }\end{array}$ & $\begin{array}{l}184 \\
221\end{array}$ & $\begin{array}{l}45.4 \\
54.6\end{array}$ \\
\hline $\begin{array}{l}\text { Presence of documented } \\
\text { diabetes-related complications }\end{array}$ & $\begin{array}{l}\text { Yes } \\
\text { No }\end{array}$ & $\begin{array}{l}161 \\
244\end{array}$ & $\begin{array}{l}39.8 \\
60.2\end{array}$ \\
\hline
\end{tabular}

Abbreviations: DM, diabetes mellitus; FBS, fasting blood sugar.

\section{Factors Associated with Self-Care \\ Practice}

To identify the predictors of self-care practice that were independently associated with self-care practice, all predictors having a $\mathrm{p}<0.20$ on bivariate analysis, were included in a logistic regression model. Accordingly, educational status, DM education, types of DM, family history of DM, knowledge about DM, knowing current fasting blood sugar, treatment satisfaction, current treatment, and
Table 3 Diabetes Knowledge Among the Study Population at Debre Berhan Referral Hospital, Northeast Ethiopia, 2019 $(n=405)$

\begin{tabular}{|c|c|c|}
\hline Variables & Category & $\begin{array}{l}\text { Frequency } \\
\text { (\%) }\end{array}$ \\
\hline $\begin{array}{l}\text { Eating food lower in fat reduces the } \\
\text { risk of developing an adverse } \\
\text { outcome in different organ }\end{array}$ & $\begin{array}{l}\text { Yes } \\
\text { No } \\
\text { Not sure }\end{array}$ & $\begin{array}{l}347(85.7) \\
17(4.2) \\
4 I(10.1)\end{array}$ \\
\hline $\begin{array}{l}\text { Does exercise has effects on blood } \\
\text { glucose? }\end{array}$ & $\begin{array}{l}\text { Yes } \\
\text { No } \\
\text { Not sure }\end{array}$ & $\begin{array}{l}317(78.3) \\
26(6.4) \\
62(15.3)\end{array}$ \\
\hline $\begin{array}{l}\text { Skip breakfast during the morning } \\
\text { while blood glucose }\end{array}$ & $\begin{array}{l}\text { Increase } \\
\text { blood } \\
\text { glucose } \\
\text { Decrease } \\
\text { blood } \\
\text { glucose } \\
\text { Remain the } \\
\text { same } \\
\text { Not sure }\end{array}$ & $\begin{array}{l}149(36.8) \\
207(5 \mathrm{I} .1) \\
18(4.4) \\
31(7.7)\end{array}$ \\
\hline $\begin{array}{l}\text { If you do not take your diabetic } \\
\text { medicine prescribed by your doctor } \\
\text { your blood glucose level will usually? }\end{array}$ & $\begin{array}{l}\text { Increase } \\
\text { Decrease } \\
\text { Remain the } \\
\text { same } \\
\text { Not sure }\end{array}$ & $\begin{array}{l}309(76.3) \\
32(7.9) \\
11(2.7) \\
53(13.1)\end{array}$ \\
\hline $\begin{array}{l}\text { The better method for monitoring } \\
\text { diabetic control }\end{array}$ & $\begin{array}{l}\text { Urine } \\
\text { testing } \\
\text { Blood } \\
\text { testing } \\
\text { Both are } \\
\text { equally } \\
\text { good } \\
\text { Not sure }\end{array}$ & $\begin{array}{l}13(3.2) \\
297(73.3) \\
81(20.0) \\
14(3.5)\end{array}$ \\
\hline $\begin{array}{l}\text { Infection can have related to the } \\
\text { blood glucose level }\end{array}$ & $\begin{array}{l}\text { Increase } \\
\text { blood } \\
\text { glucose } \\
\text { Decrease } \\
\text { blood } \\
\text { glucose } \\
\text { No change } \\
\text { Not sure }\end{array}$ & $\begin{array}{l}49(12.1) \\
128(31.6) \\
67(16.5) \\
161(39.8)\end{array}$ \\
\hline $\begin{array}{l}\text { Can cause exercise high blood } \\
\text { glucose }\end{array}$ & $\begin{array}{l}\text { Yes } \\
\text { No } \\
\text { Not sure }\end{array}$ & $\begin{array}{l}67(16.5) \\
221(54.6) \\
117(28.9)\end{array}$ \\
\hline $\begin{array}{l}\text { High blood glucose can be caused by } \\
\text { taking too much fruit? }\end{array}$ & $\begin{array}{l}\text { Yes } \\
\text { No } \\
\text { Not sure }\end{array}$ & $\begin{array}{l}123(30.4) \\
207(5 \mid .1) \\
75(I 8.5)\end{array}$ \\
\hline
\end{tabular}

(Continued) 
Table 3 (Continued).

\begin{tabular}{|c|c|c|}
\hline Variables & Category & $\begin{array}{l}\text { Frequency } \\
\text { (\%) }\end{array}$ \\
\hline Eye problem & $\begin{array}{l}\text { Yes } \\
\text { No } \\
\text { Not sure }\end{array}$ & $\begin{array}{l}315(77.8) \\
43(10.6) \\
47(11.6)\end{array}$ \\
\hline Kidney problem & $\begin{array}{l}\text { Yes } \\
\text { No } \\
\text { Not sure }\end{array}$ & $\begin{array}{l}312(77.0) \\
35(8.6) \\
58(14.3)\end{array}$ \\
\hline Heart problem & $\begin{array}{l}\text { Yes } \\
\text { No } \\
\text { Not sure }\end{array}$ & $\begin{array}{l}333(82.2) \\
27(6.7) \\
45(11.1)\end{array}$ \\
\hline Lung problem & $\begin{array}{l}\text { Yes } \\
\text { No } \\
\text { Not sure }\end{array}$ & $\begin{array}{l}|4|(34.8) \\
8 \mid(20.0) \\
\mid 83(45.2)\end{array}$ \\
\hline Nerve problem & $\begin{array}{l}\text { Yes } \\
\text { No } \\
\text { Not sure }\end{array}$ & $\begin{array}{l}222(54.8) \\
33(8.1) \\
150(37.1)\end{array}$ \\
\hline Stroke & $\begin{array}{l}\text { Yes } \\
\text { No } \\
\text { Not sure }\end{array}$ & $\begin{array}{l}176(43.4) \\
55(13.6) \\
174(43.0)\end{array}$ \\
\hline Foot problem & $\begin{array}{l}\text { Yes } \\
\text { No } \\
\text { Not sure }\end{array}$ & $\begin{array}{l}35 \text { I (86.7) } \\
28(6.9) \\
26(6.4)\end{array}$ \\
\hline
\end{tabular}

presence of comorbidity were entered into multivariate analysis. On a multivariate logistic regression analysis educational status of the participants (with no formal education $(\mathrm{AOR}=0.12,95 \% \mathrm{CI}: 0.03-0.42)$, can read and write $(\mathrm{AOR}=0.23,95 \% \mathrm{CI}$ : $0.07-0.75)$, secondary school (AOR $=0.28,95 \%$ CI: $0.09-0.88)$ ), type $1 \mathrm{DM}(\mathrm{AOR}=0.27$, 95\% CI: $0.09-0.79$ ), family history of $\mathrm{DM}(\mathrm{AOR}=3.71$, 95\% CI: 1.37-10.07), and treatment satisfaction ( $\mathrm{AOR}=4.41,95 \% \mathrm{CI}: 1.52-8.59)$ were significantly associated with self-care practice (Table 6).

\section{Discussion}

In this institution-based cross-sectional study self-care practice and associated factors among individuals with DM at Debre Berhan referral hospital have been assessed. The study found that 181 (44.7\%) DM patients had good self-care practices. Moreover, educational status, types of $\mathrm{DM}$, family history of DM, and treatment satisfaction were significantly associated with self-care practice.

In this study, good self-care practice was lower than the study done in Addis Ababa public hospital 60.3\%, ${ }^{6} \mathrm{Jimma}$

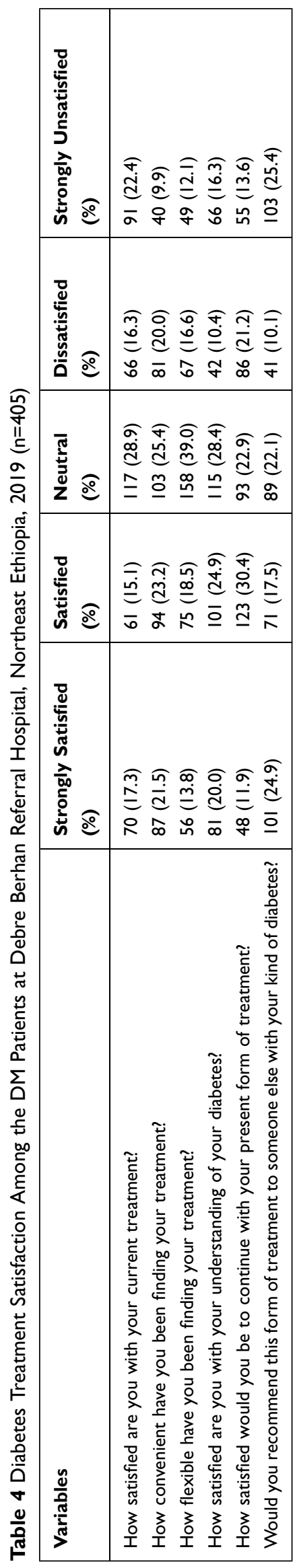


Table 5 Diabetic Self-Care Practice Among Diabetes Mellitus Patients at Debre Berhan Referral Hospital, Northeast Ethiopia, 2019 $(n=405)$

\begin{tabular}{|c|c|c|}
\hline Variables & $\begin{array}{l}\text { Self-Care } \\
\text { Practice }\end{array}$ & $\begin{array}{l}\text { Frequency } \\
\text { (\%) }\end{array}$ \\
\hline $\begin{array}{l}\text { On how many of the last seven days do you participate in at least } 30 \text { minutes of physical activity (total minutes } \\
\text { continuous activity including walking).? }\end{array}$ & $\begin{array}{l}\text { Good } \\
\text { Poor }\end{array}$ & $\begin{array}{l}244(60.2) \\
161(39.8)\end{array}$ \\
\hline $\begin{array}{l}\text { On how many of the last seven days do you participate in specific exercise sessions (such as swimming, walking, } \\
\text { biking) other than what you do around house or as part of your work? }\end{array}$ & $\begin{array}{l}\text { Good } \\
\text { Poor }\end{array}$ & $\begin{array}{l}144(35.6) \\
261(64.4)\end{array}$ \\
\hline On how many of the last 7 days, did you take your recommended diabetes medication? & $\begin{array}{l}\text { Good } \\
\text { Poor }\end{array}$ & $\begin{array}{l}355(87.7) \\
50(12.3)\end{array}$ \\
\hline On how many of the last seven days did you check your feet? & $\begin{array}{l}\text { Good } \\
\text { Poor }\end{array}$ & $\begin{array}{l}240(59.3) \\
165(40.7)\end{array}$ \\
\hline On how many of the last seven days did you inspect the inside of your shoes? & $\begin{array}{l}\text { Good } \\
\text { Poor }\end{array}$ & $\begin{array}{l}171(42.2) \\
234(57.8)\end{array}$ \\
\hline For how many of the last seven days do you wash your feet? & $\begin{array}{l}\text { Good } \\
\text { Poor }\end{array}$ & $\begin{array}{l}211(52.1) \\
194(47.9)\end{array}$ \\
\hline For how many of the last seven days do you soak your feet? & $\begin{array}{l}\text { Good } \\
\text { Poor }\end{array}$ & $\begin{array}{l}169(41.7) \\
236(58.3)\end{array}$ \\
\hline For how many of the last seven days Do you dry between your toes after washing? & $\begin{array}{l}\text { Good } \\
\text { Poor }\end{array}$ & $\begin{array}{l}201(49.6) \\
204(50.4)\end{array}$ \\
\hline How many of the last 7 days have you followed a healthful eating plan? & $\begin{array}{l}\text { Good } \\
\text { Poor }\end{array}$ & $\begin{array}{l}|3|(32.3) \\
274(67.7)\end{array}$ \\
\hline On average over the past months how many days per week have you followed a healthy eating plan? & $\begin{array}{l}\text { Good } \\
\text { Poor }\end{array}$ & $\begin{array}{l}147(36.3) \\
258(63.7)\end{array}$ \\
\hline On how many of the last seven days did you eat five or more serving of fruits and vegetables? & $\begin{array}{l}\text { Good } \\
\text { Poor }\end{array}$ & $\begin{array}{l}182(55.1) \\
223(44.9)\end{array}$ \\
\hline On how many of the last 7 days did you space carbohydrates evenly through the day? & $\begin{array}{l}\text { Good } \\
\text { Poor }\end{array}$ & $\begin{array}{l}175(56.8) \\
230(43.2)\end{array}$ \\
\hline How many of the last seven days did you eat high-fat foods like red meat or full-fat dairy products? & $\begin{array}{l}\text { Good } \\
\text { Poor }\end{array}$ & $\begin{array}{l}208(5 \mathrm{I} .4) \\
197(48.6)\end{array}$ \\
\hline On how many of the last 7 days, did you take your recommended diabetes medication? & $\begin{array}{l}\text { Good } \\
\text { Poor }\end{array}$ & $\begin{array}{l}102(25.2) \\
303(74.8)\end{array}$ \\
\hline $\begin{array}{l}\text { On how many of the last } 7 \text { days did you test your blood sugar the number of times recommended by your health } \\
\text { care provider? }\end{array}$ & $\begin{array}{l}\text { Good } \\
\text { Poor }\end{array}$ & $\begin{array}{l}100(24.7) \\
305(75.3)\end{array}$ \\
\hline Over all diabetic self-care practice & $\begin{array}{l}\text { Good } \\
\text { Poor }\end{array}$ & $\begin{array}{l}181(44.7) \\
224(55.3)\end{array}$ \\
\hline
\end{tabular}

University specialized hospital $(55 \%),{ }^{10}$ Eastern Ethiopia $(60.7 \%),{ }^{11}$ Qatar $(88.9 \%),{ }^{12}$ Kenya $(59 \%),{ }^{13}$ Nigeria $(80.3 \%),{ }^{14}$ and Dilla University referral hospital $(76.8 \%)^{15}$ but higher than the study conducted at United Arabia Emirates (15.3\%), ${ }^{16}$ and Mexico (33.5\%). ${ }^{17}$ This might be due to differences in the source population, socio-economic and cultural difference, level of health care facility as well as the type of tools used to measure the self-care practice and treatment satisfaction.

In line with the study conducted in Jimma University specialized hospital ${ }^{10}$ and Nekemt, Western Ethiopia, ${ }^{18}$ in this study more than half of the study participants had poor diabetes knowledge. This may be due to the absence of regular diabetes education in the hospital and participants' 
Table 6 Factors Associated with Diabetic Self-Care Practice Among DM Patients at Debre Berhan Referral Hospital, 20I9 ( $\mathrm{n=405)}$

\begin{tabular}{|c|c|c|c|c|}
\hline \multirow[t]{2}{*}{ Variables } & \multicolumn{2}{|c|}{ Self-Care Practice } & \multirow[t]{2}{*}{ COR $(95 \% \mathrm{Cl})$} & \multirow[t]{2}{*}{ AOR $(95 \% \mathrm{Cl})$} \\
\hline & Good N (\%) & Poor N (\%) & & \\
\hline \multicolumn{5}{|l|}{ Educational status } \\
\hline No formal education & $28(24.6)$ & $86(75.4)$ & $0.19(0.09-0.39)$ & $0.12(0.03-0.42)^{*}$ \\
\hline Can read and write & $48(47.1)$ & $54(52.9)$ & $0.52(0.27-1.28)$ & $0.23(0.07-0.75)^{*}$ \\
\hline Primary school & $26(50)$ & $26(50)$ & $0.59(0.27-1.03)$ & 0.31 (0.09-1.07) \\
\hline Secondary school & $45(54.2)$ & $38(45.8)$ & $0.70(0.35-1.40)$ & $0.28(0.09-0.88)^{*}$ \\
\hline College and above & $34(63)$ & $20(37)$ & 1.00 & 1.00 \\
\hline \multicolumn{5}{|l|}{ Diabetic education } \\
\hline Regularly & $25(58.1)$ & $18(41.9)$ & $2.66(1.85-9.58)$ & $3.46(0.45-8.86)$ \\
\hline Sometimes & $83(55.7)$ & $66(44.3)$ & $2.41(1.17-9.36)$ & $5.24(0.68-9.53)$ \\
\hline Never & $73(34.7)$ & $140(65.3)$ & 1.00 & 1.00 \\
\hline \multicolumn{5}{|l|}{ Type of DM } \\
\hline Type I & $36(28.8)$ & 89 (7I.2) & $0.38(0.13-3.36)$ & $0.27(0.09-0.79)^{*}$ \\
\hline Type 2 & $145(51.8)$ & $135(48.2)$ & 1.00 & 1.00 \\
\hline \multicolumn{5}{|l|}{ Comorbidity } \\
\hline Yes & $43(35.0)$ & $80(65.0)$ & $0.56(0.02-2.16)$ & $1.18(0.67-2.06)$ \\
\hline No & $138(48.9)$ & $144(51.1)$ & 1.00 & 1.00 \\
\hline \multicolumn{5}{|l|}{ Current treatment } \\
\hline Insulin & $97(51.6)$ & 91 (48.4) & $1.69(1.05-2.32)$ & $1.03(0.53-2.01)$ \\
\hline Oral & $84(38.7)$ & $133(61.3)$ & 1.00 & 1.00 \\
\hline \multicolumn{5}{|l|}{ Diabetic knowledge } \\
\hline Adequate & $102(59.3)$ & $70(40.7)$ & $2.84(1.46-5.30)$ & $3.47(0.20-4.29)$ \\
\hline Inadequate & 79 (33.9) & I54 (66.I) & 1.00 & 1.00 \\
\hline \multicolumn{5}{|l|}{ Family history of DM } \\
\hline Yes & 81 (54.4) & $68(45.6)$ & $1.86(0.40-3.75)$ & $3.71(1.37-10.07)^{*}$ \\
\hline No & $100(39.1)$ & $156(60.9)$ & 1.00 & 1.00 \\
\hline \multicolumn{5}{|l|}{ Knowing current FBS } \\
\hline Yes & $164(46.7)$ & $187(53.3)$ & $1.91(1.07-9.97)$ & $3.39(0.02-6.63)$ \\
\hline No & $17(31.5)$ & $37(68.5)$ & 1.00 & 1.00 \\
\hline \multicolumn{5}{|l|}{ Treatment satisfaction } \\
\hline Satisfied & $161(53.0)$ & $143(47.0)$ & $4.56(1.01-7.61)$ & $4.41(1.52-8.59) *$ \\
\hline Unsatisfied & $20(19.8)$ & $81(80.2)$ & 1.00 & 1.00 \\
\hline
\end{tabular}

Note: *Statistically significant at $\mathrm{P}<0.05$.

educational status in which more than half of the study participants were with lower educational status.

Unlike the study in the Hadiya zone, Southern Ethiopia in which more than half of participants were satisfied with the current treatment, in this study nearly three-fourths of the participants were unsatisfied with the current treatment. This increased number of participants with poor treatment satisfaction in this study may be due to the difference in physician to patients' ratio, and availability of adequate treatment and diagnostic equipment.
In this study respondents with lower educational status were less likely to had good self-care practice compared with those who had college and above educational status. This finding is similar to the study in Western Ethiopia, ${ }^{18}$ Addis Ababa, ${ }^{19}$ Southwest Ethiopia, ${ }^{20}$ and Southern India. ${ }^{21}$ This might be due to the fact that realizing and awareness of self-care practice and commitment for adhering to the self-care practices, improved with an increased level of education. Thus education on self-care practices has to be provided for all individuals with diabetes mellitus. 
Respondents with a family history of DM were nearly four times more likely to practiced self-care practice as compared to participants with no family history of DM. This may be due to participants with a family history of DM have the opportunity of gating family support as their family may become familiar with self-care management of DM. Individuals who have a family history of DM could also have better information related to the disease, and have a chance to get an education.

It was also likely that the difference in self-care practice might result from differences in treatment satisfaction. Compared to respondents with unsatisfied with current treatments, respondents with satisfied with the current treatment had greater odds for self-care practice. This finding is comparable with the result of the study in Southern Ethiopia, ${ }^{9}$ Eastern Ethiopia, ${ }^{22}$ and in Addis Ababa public hospital. ${ }^{6}$ Since individual treatment satisfaction is directly associated with the degree of satisfaction with each health care activities and is linked with self-care practice. This suggests health care providers should enhance self-care practice by emphasizing patients' treatment satisfaction through different strategies.

\section{Limitations}

Due to the cross-sectional nature of the study, the causeeffect relationship was not identified; data were collected by self-report rather than observation which leads to bias and AADE7 Self-Care Behaviors was not assessed were the limitation of the study.

\section{Conclusion}

In conclusion, more than half of respondents had inadequate self-care practices. Educational status, types of DM, family history of DM, and treatment satisfaction were the predictor of self-care practice.

\section{Abbreviations}

DBRH, Debre Berhan Referral Hospital; DM, diabetes mellitus; DTSQ, diabetes treatment satisfaction questionnaire; FBS, fasting blood sugar; SMBG, self-monitoring of blood glucose; OHA, oral hypoglycemic agents; SDSCA, Summary of Diabetes Self-Care Activities.

\section{Data Sharing Statement}

The datasets used and/or analyzed during this study are available from the corresponding author on reasonable request.

\section{Ethics Approval and Informed Consent}

The study was conducted in accordance with the ethical standard of the Helsinki Declaration. The ethical clearance for the study was obtained from the Ethical Review Board (IRB) Debre Berhan University. Then, a permission letter to conduct the study was obtained from the Debre Berhan referral hospital. Before the actual data collection procedures, written informed consent was obtained. For the participants under the age of 18 , informed consent was taken from their parent and also assent was taken from the participant. Participation was voluntary and participants had the right to refuse or withdraw at any time in the data collection periods. All the exit interviews were made under strict privacy.

\section{Acknowledgments}

We are grateful to Debre Berhan University for logistic support for this study. We are also very grateful to Debre Berhan referral hospital DM clinic staff for their teamwork in the study. Finally, our deepest gratitude goes to the study participants for providing the required information for this study.

\section{Author Contributions}

All authors made a significant contribution to the work reported, whether that is in the conception, study design, execution, acquisition of data, analysis and interpretation, or in all these areas; took part in drafting, revising or critically reviewing the article; gave final approval of the version to be published; have agreed on the journal to which the article has been submitted; and agree to be accountable for all aspects of the work.

\section{Funding}

The authors received no financial support for this study and the study was funded by the authors.

\section{Disclosure}

The authors declare that they have no competing interests.

\section{References}

1. American Diabetes Association. Standards of medical care in diabetes -2020. Diabetes Care. 2020;43(Supplement 1):S1-S2. doi:10.2337/ dc20-Sint

2. Harding JL, Pavkov ME, Magliano DJ, et al. Global trends in diabetes complications: a review of current evidence. Diabetologia. 2019;62:3-16. doi:10.1007/s00125-018-4711-2 
3. Assah. Urbanization, physical activity and metabolic health in Sub-Saharan Africa. Diabet Care. 2011;34:491-496. doi:10.2337/ dc10-0990

4. Abebaw M, Messele A, Hailu M, Zewdu F. Adherence and associated factors towards antidiabetic medication among type II diabetic patients on follow-up at University of Gondar Hospital, Northwest Ethiopia. Adv Nurs. 2016;2016:1-7. Hindawi Publishing Corporation. doi:10.1155/2016/8579157

5. Dedefo MG, Ejeta BM, Wakjira GB, et al. Self-care practices regarding diabetes among diabetic patients in West Ethiopia. BMC Res Notes. 2019;12:212. doi:10.1186/s13104-019-4258-4

6. Mamo M, Demissie M. Self care practice and its associated factors among diabetic patients in addisababa public hospitals, cross sectional study. J Diabetes Cholest Metabol. 2016;1(1):2-5.

7. American Diabetes Association. Standards of medical care in diabetes-2014. Diabetes Care. 2014;37(Suppl 1):S14-S80. PMID: 24357209. doi:10.2337/dc14-S014

8. Toobert DJ, Hampson SE, Glasgow RE. The summary of diabetes self-care activities measure: results from 7 studies and a revised scale. Diabetes Care. 2000;23(7):943-950. doi:10.2337/diacare.23.7.943

9. Gadore TF, Dea YC, Taddele BW. Predictors of diabetes self-care practice and associated factors among patient on follow up at Hadiya Zone, Health Institutions Southern Ethiopia, using health belief model, cross-sectional study design. EC Endocrinol Metab Res. 2019;4:01-17.

10. Endalew H, Mariam WH, Belachew T, Birhanu Z, Health F. Selfe-care practice and glycemic control among adults with diabetes at Jimma University specialized Hospital in south west Ethiopia: across-sectional study. Afr J Prm Health Care Farm Med. 2012;4(1):1-6.

11. Ayele K, Tesfa B, Abebe L, Tilahun T, Girma E. Self care behavior among patients with diabetes in Harari, Eastern Ethiopia: the health belief model perspective. PLoS One. 2012;7(4):e35515. doi:10.1371/ journal.pone. 0035515

12. Mesmar M, Eljack A, Al-Kuwari MG. Knowledge and practice of type 2 diabetic patients attending primary health care in Qatar. Middle East J Family Med. 2011;9(4):3-10.

13. Maina WK, Ndegwa ZM, Njenga EW, Muchemi EW. Knowledge, attitude and practices related to diabetes among community members in four provinces in Kenya: a cross-sectional study. Pan Afr Med J. 2010;7(1)
14. Okolie VU, Ehiemere OI, Peace IN, Ngozi KI. Knowledge of diabetes management by diabetic patients at Federal Medical Center Umuahia Abia State, Nigeria. Int J Med Med Sci. 2009;1(9):353-358.

15. Addisu Y, Eshete A, Hailu E. Assessment of diabetic patient perception on diabetic disease and self-care practice in Dilla University Referral Hospital. South Ethiop J Metab Synd. 2014;3:166.

16. Al-Maskari F, El-Sadig M, Al-Kaabi JM, Afandi B, Nagelkerke N, Yeatts KB. Knowledge, attitude and practices of diabetic patients in the United Arab Emirates. PLoS One. 2013;8(1):e52857. doi:10.1371/journal.pone.0052857

17. Baquedano IR, Santos MA, Martins TA, Zanetti ML. Self-care of patients with diabetes mellitus cared for at an emergency service in Mexico. Rev Lat Am Enfermagem. 2010;18(6):1195-1202. doi:10.1590/S0104-11692010000600021

18. Amente T, Belachew T, Hailu E, Berhanu N. Self care practice and its predictors among adults with diabetes mellitus on follow up at Nekemte hospital diabetic clinic, West Ethiopia. World J Med Med Sci. 2014;2(3):1-6.

19. Bonger Z, Shiferaw S, Tariku EZ. Adherence to diabetic self-care practices and its associated factors among patients with type 2 diabetes in Addis Ababa, Ethiopia. Patient Prefer Adherence. 2018;12:963. doi:10.2147/PPA.S156043

20. Kassahun T, Gesesew H, Mwanri L, Eshetie T. Diabetes related knowledge, self-care behaviours and adherence to medications among diabetic patients in Southwest Ethiopia: a cross-sectional survey. BMC Endocr Disord. 2016;16(1):28. doi:10.1186/s12902016-0114-x

21. Hemavathi Dasappa SP, Sirisha M, Prasanna SR, Naik S. Prevalence of self-care practices and assessment of their sociodemographic risk factors among diabetes in the urban slums of Bengaluru. $J$ Family Med Prim Care. 2017;6(2):218. doi:10.4103/2249-4863.220037

22. Getie A, Geda B, Alemayhu T, Bante A, Aschalew Z, Wassihun Alemu B. Self-care practices and associated factors among adult diabetic patients in public hospitals of dire dawa administration, Eastern Ethiopia. BMC Public Health. 2020;20:1232. doi:10.1186/ s12889-020-09338-5
Journal of Multidisciplinary Healthcare

\section{Publish your work in this journal}

The Journal of Multidisciplinary Healthcare is an international, peerreviewed open-access journal that aims to represent and publish research in healthcare areas delivered by practitioners of different disciplines. This includes studies and reviews conducted by multidisciplinary teams as well as research which evaluates the results or conduct of such teams or healthcare processes in general. The journal

\section{Dovepress}

covers a very wide range of areas and welcomes submissions from practitioners at all levels, from all over the world. The manuscript management system is completely online and includes a very quick and fair peer-review system. Visit http://www.dovepress.com/testimonials. php to read real quotes from published authors. 